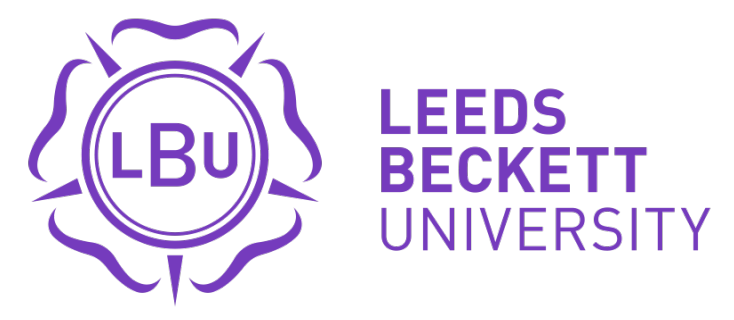

Citation:

Raisborough, J and Ogden, C and de Guzman, V (2019) When fat meets disability in poverty porn: exploring the cultural mechanisms of suspicion in Too Fat to Work. Disability and Society, 34 (2). pp. 276-295. ISSN 0968-7599 DOI: https://doi.org/10.1080/09687599.2018.1519408

Link to Leeds Beckett Repository record:

https://eprints.leedsbeckett.ac.uk/id/eprint/5277/

Document Version:

Article (Accepted Version)

This is an Accepted Manuscript of an article published by Taylor \& Francis in Disability and Society on 29 December 2018, available online: http://www.tandfonline.com/10.1080/09687599.2018.1519408

The aim of the Leeds Beckett Repository is to provide open access to our research, as required by funder policies and permitted by publishers and copyright law.

The Leeds Beckett repository holds a wide range of publications, each of which has been checked for copyright and the relevant embargo period has been applied by the Research Services team.

We operate on a standard take-down policy. If you are the author or publisher of an output and you would like it removed from the repository, please contact us and we will investigate on a case-by-case basis.

Each thesis in the repository has been cleared where necessary by the author for third party copyright. If you would like a thesis to be removed from the repository or believe there is an issue with copyright, please contact us on openaccess@leedsbeckett.ac.uk and we will investigate on a case-by-case basis. 


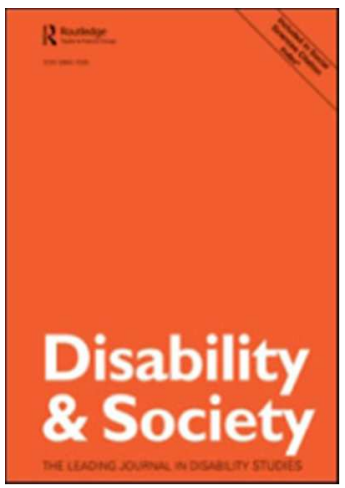

\section{When fat meets disability in poverty porn: exploring the cultural mechanisms of suspicion in Too Fat to Work'}

\begin{tabular}{|r|l|}
\hline Journal: & Disability \& Society \\
\hline Manuscript ID & CDSO-2017-0308.R2 \\
\hline Manuscript Type: & Original Article \\
\hline Keywords: & Austerity, benefits, poverty porn, media representations, reality television \\
\hline Abstract: & $\begin{array}{l}\text { There has been a distinct neglect of dis/ability in socio-cultural analysis of } \\
\text { poverty porn (Runswick-Cole and Goodley 2015). This paper applies } \\
\text { framing analysis to reality TV documentaries that feature larger bodied, } \\
\text { disabled, welfare claimants to examine how cultural literacies of fatness } \\
\text { and 'obesity' are drawn upon to cast suspicion upon disability welfare } \\
\text { claimants in so-called poverty- porn. With a focus on Channel 5's Benefit } \\
\text { Britain series, Benefits Too Fat to Work we demonstrate that enduring and } \\
\text { harmful representations of 'obesity' are put to the work of securing public } \\
\text { consent for a post-welfare society in the UK }\end{array}$ \\
\hline
\end{tabular}




\section{Points of interest}

- We examine how disability welfare claimants are represented in reality television programmes that document the lives of unemployed people in the UK

- We argue that disability welfare claimants are mainly represented as fat and obese

- We argue that obesity serves a specific function in reality welfare programmes: commonsense understandings that weight is controllable can cast doubt on the authenticity of peoples' impairments and on their entitlement to welfare support.

- We argue that these programmes circulate harmful representations of fat and disability and may serve to help secure public support for benefits cuts. 
Title When fat meets disability in poverty porn: exploring the cultural mechanisms of suspicion in Too Fat to Work.

Raisborough, J.; Ogden, C.; de Guzman, V.

Key words: Austerity, benefits, disability welfare, poverty porn, suspicion.

\section{Introduction: poverty porn as a site for study}

Since the North Atlantic Financial crash in 2008, there has been a recent proliferation of reality television documentaries that feature people who claim social security in western countries. Programmes include Australia's Struggle Street, Ireland's Benefit Estate and America's My Reality; Hidden America, In the UK Benefits Street is perhaps the best known. It documented the lives of people residing on James Turner Street in Birmingham where, as it was widely and inaccurately reported, some $90 \%$ of residents were in receipt of social security benefits. Benefits Street earned Channel 4 some of its highest viewing figures in 2014, which might explain why similar programming is now a regular feature on UK television schedules. Channel 5, for example, aired two series of Benefits Britain: Life on the Dole and their fourth series of On Benefits screened its $15^{\text {th }}$ episode at the time of writing in July 2017 (http://www.channel5.com/show/on-benefits/). The producers of these UK shows consider them to be of public interest because they offer a 'voice to the disenfranchised' and 'those who have been hit hardest by austerity' while showing the 'reality of life on welfare' (Mirsky 2014: also see De Benedictis, Allen, and Jensen 2017). The Radio Times, a leading UK TV listing magazine, classify these documentaries as 'education'.

Yet, many critics argue that these documentaries are little more than 'poverty porn' 
because they circulate benefit stigma - the shaming of people who claim social security support (Jensen 2013a; Allen, Tyler, and De Benedictis 2014). Brooker et al's (2015) analysis of the twitter streams that accompanied Benefits Street found that the majority of tweets were 'abusive or, perhaps, jokingly pejorative' (p. 3185) towards the claimants and also mocked the UK social security system itself. Similarly, Right-wing politicians have cited poverty porn programming as evidence of a failing benefit system that is in urgent need of radical reform (Deeming 2015). Yet, benefit shame is not directed with the same vitriol to all of those who draw social security: representations of the poor are heavily classed and racialized. The white working class are particularly vilified in this genre for their presumed immoral, workshy attitudes and their so-called 'addiction' to lifestyles of welfare dependency (MacDonald, Shildrick, and Furlong 2014; Morris 2016). This personalization of poverty is argued to shift the blame for economic hardship from the elite towards marginalized groups (Wacquant 2008). It also helps to present austerity savings (benefits cuts) as logical solutions to the 'problem' of welfare dependency (O'Flynn, Monaghan, and Power 2014). There are good reasons then, why scholars are concerned about the role of poverty porn in manufacturing public consent for benefits cuts and for a move to a post-welfare society in the UK (Jensen and Tyler 2015; Biressi and Nunn 2013).

While classed and racialized representations in poverty porn have attracted much needed critical attention, representations of dis/ability have been neglected as they are in wider socio-cultural analysis (Runswick-Cole and Goodley 2015). We aim to help address this neglect but we want to stress that an analysis of representations of 
dis/abilty in poverty porn is not simply a redemptive exercise of adding dis/ability into the analytic mix. Briant, Watson, and Philo (2013) argue that pronounced social and cultural exclusions of disabled people from wider society mean that negative media representations can play a major role in influencing public attitudes to disability and may be internalized by disabled people. Less 'negative' representations are also problematic: in her analysis of American reality television, Clearly $(2016,1)$ observed that when disabled people are represented, it is only 'specific bodies heterosexual, white, gender normative, affluent — are called upon to perform disability'. She has concerns about the de-politicising consequences when media representations divorce disabled people from wider material conditions and forms of stratifying power. Our focus on poverty porn may go some way to reveal differently classed representations, yet representations of disabled people in a genre implicated in 'scroungerphobia' (Heeney 2015, 652) constitutes a real concern, not least because disabled people are actively made unemployable through disabled prejudice (Bates, Goodley, and Runswick-Cole_2017; Flint and Snook 2014).

To this important point we wish to add that a focus on dis/ability in poverty porn can also help us to understand the cultural mechanisms used to normalise wider neoliberal, ablest, austerity logics in the UK. This is because although disabled people are the hardest hit by the precarity of austerity and its cuts (Bates, Goodley, and Runswick-Cole 2017; Soldatic and Morgan 2017), there is, at different times, 'a great deal of public sympathy and support for disabled people' (Briant, Watson, and Philo 2013, 885). Watkins-Hayes and Kovalsky $(2017,194)$ have recently listed disabled people amongst those regarded as the 'deserving poor' because they 'are thought to be unable to work through no fault of their own and therefore have a legitimate claim to resources'. These public perceptions of 'deserving claimants' can 
make explicit threats to disability welfare risky for politicians. They can also make the accusation of scrounger harder to apply and can even disrupt the manufacture of public consent for austerity measures aimed at disabled people (Runswick- Cole and Goodley 2015).

Just how this potential for disruption is limited or managed can reveal much about the workings of neoliberal reproduction. Some work has started this project: for example, Briant, Watson, and Philo's (2013) analysis of newspapers observed how the deliberate and repeated constructions of a 'fraudulent' disability welfare claimant allowed cuts to be presented as necessary reforms to protect the tax-payer and those in 'genuine' need of disability support. This strategic deployment of fairness enabled austerity measures to manifest as being on the side of particular disability welfare claimants, indeed championing their cause and right to welfare, while instigating a number of punitive, harmful testing regimes and eligibility criteria against the entire claimant population. Additionally, Runswick-Cole and Goodley's (2015) sharp attention to Benefits Street and its media coverage noted how careful distinctions were constructed between impairments: emotional and mental health issues were presented as suspicious entitlements to welfare whereas learning difficulties attracted more sympathetic coverage and offered a 'label of forgiveness' (p. 647) for unemployment. Runswick-Cole and Goodley concluded that different impairments do different cultural work in the representational space of poverty porn: by foregrounding purportedly 'suspicious' disabilities, Benefits Street provided a 'narrative prosthesis' $(2015,647)$ for public perceptions of a widespread corruption of a failing system by undeserving, notably white working class, welfare claimants. These examples reveal something of the cultural strategies used to exclude and marginalise groups in the purported interests of good/ responsible fiscal governance. 
We wish to add to this important work by examining the cultural mechanisms of suspicion in a recent spate of poverty porn that explicitly feature claimants who are labeled obese: examples include Benefits and Bypasses: Billon Pound Patients; Shut ins: Britain's Fattest People; 87 Stone: Fat Chance of Work; Too Fat to Work; 65 Stone and Trapped in My Own House. In what follows we explore the cultural work performed by representations of obesity in framing illness, impairments and mobility issues as the consequence of faulty lifestyles and immoral character traits. Our intention is not to argue that obesity or fatness should be regarded as a form of disability or as a disability issue (see Aphramor [2009] for this discussion), rather our work focuses on the representations of obesity and those of disability welfare claimants in the genre of reality television poverty porn documentaries to examine how public consent for austerity cuts may be procured.

\section{Framing in poverty porn}

In this paper we focus on Benefits: Too Fat to Work, first broadcast in December 2015, which forms part of C5's 'Benefits' series. We selected Bene£its for two main reasons. The first is that it is representative of other reality documentaries in what is a highly formulaic genre. For example, it involves fly-on-the-wall footage of individuals who live in different geographical areas that are coded as working-class or poor and features an off-screen narrator whose narration flows in and around carefully edited quotes from the participants. The second reason for our choice relates to the wider media attention received by key participants Steve and Michelle Beer, upon whom we focus in this paper. Bene£its filmed Steve and Michelle as they planned and executed their wedding. Dubbed the 'couple with the benefits' wedding', the Beers 
were interviewed on the UK television breakfast magazine show This Morning and they were guests on ITV's Jeremy Kyle Show. They also featured across the tabloid press. The Daily Mail headline on the $20^{\text {th }}$ December 2015 'Couple who had their $£ 3,000$ wedding paid for by the tax-payer because they are 'too fat to work' celebrate their first wedding anniversary with a KFC' is typical of the media coverage as a whole. Just how the 'wedding paid for by the tax-payer' was framed in Benefits may give some insight into a deepening of suspicion of disability welfare recipients that is based both on contesting 'authentic' disabilities and upon 'appropriate' benefit spending Additionally, the wider attention received by the Beers is significant because as Tyler (2008) argues it is through repetition across different sites that abject 'grotesque and comic figures' (Tyler 2008,17) can act as 'consensus apparatus' $(2013,25)$, generating public sympathy for austerity measures, even when these measures 'frequently curtail the freedoms of all citizens and further impoverish democracy' $(2013,10)$.

We approached Bene£its' representation of the Beers through frame analysis. Frames are 'schemata of interpretation' (Goffman 1974, 2), that offer simplified representations of social issues by 'selectively punctuating and encoding objects, situations, events, experiences, and sequences of action' (Snow and Benford 1992,137). Frame analysis demands attention to patterns, selection and omission because frames often reproduce moral judgements when they identify who is responsible for a social problem and who is affected by it (Jenkin, Signal, and Thomson 2012). Frame analysis is also useful for our purposes because it allows us to make links between cultural representations and their wider socio-economic contexts. There are two aspects of this: firstly, Butler (2009) explains that frames are produced 
through a condensing of current cultural norms and values, making frames not just 'politically saturated' in themselves but in their consequences when highly selective versions of social issues take hold in the cultural imaginary as a 'perceptible reality' $(2009,64)$. Our focus is, then, on how poverty documentaries 'frame' welfare, claimants and their entitlements in the context of UK austerity with attention to what values and norms are constituting the frame itself. We did this through multiple viewings to identify patterns and repetitions in representations. We were also attentive to what was foregrounded, omitted or muted by following Ghoshal (2009) to ask what other narratives or accounts might be possible.

Secondly, Butler notes how 'to frame' can also refer to 'setting up' someone to shoulder blame and responsibility: to be framed refers to having 'evidence planted' which 'proves' guilt, so that a 'guilty status becomes the viewer's inevitable conclusion' $(2009,8)$. We used this insight to think about how obese disability claimants Steve and Michelle may be 'set up' in such ways that bring the welfare system itself into doubt: we focused on the production and suggestion of accusation and assumptions of wrong-doing in our repeated viewings of the show.

\section{Why a Big Fat Frame?}

Off screen Narrator: 'Britain is getting fatter and as our waistline grows so does the burden on the benefit system'

First and foremost, disabled claimants in Bene£its Too Fat to Work are presented as 'fat'. This is explicit in the title, in the main focus of the show and in its opening line 
above. It may seem a rather obvious starting place to discuss frames, but it is worth closer examination because fat is not a neutral descriptor of body size: we start then, by asking why this frame.

Fat may be an unsurprising focus for poverty porn because overweight people are already over-represented across reality television, particularly in the glut of weightloss makeover shows over the past decade (Raisborough 2014). There is however, more to say here because, although not consistently so (Jutel 2009), fat bodies have historically served as a repository for wider socio-cultural anxieties such as classcorruption (Farrell 2011), uncontrolled consumption (Shugart 2010), poor national fitness (Monaghan, Colls and Evans 2013) and the ability of middle-class men to rebuild society after nuclear attack (McPhail 2009). A historical analysis demonstrates that negative stereotypes of fat endure but take up different expressions that reflect contemporary concerns (Grant, Mizzi, and Anglim 2016). Our current climate of neoliberal entrepreneurial individualisation is the context for stereotypes that regard fat bodies as outward signs of individuals who are 'lazy, unmotivated, lacking in self-discipline, less competent, noncompliant, and sloppy' (Puhl and Heuer 2009, 941). Fat then, readily provides a host of associations with which to overdetermine the welfare claimant in poverty porn and acts to tie individual body shapes and sizes into prevailing socio-economic crises and concerns. Yet, more specifically for our purposes, contemporary meanings of fat are also situated in the context of the obesity epidemic.

The obesity epidemic relies on translations of body fat, via the Body Mass Index (BMI), into a graduated scale ranging from 'underweight' to 'morbidly obese'. These 
gradients are significant because they serve as risk markers for a range of illnesses and diseases that are correlated with high weight (cancers, hypertension, diabetes, heart disease, mobility problems, sleep apnea, dementia, and psychological/emotion issues). The 'epidemic' refers to a population increase in BMI and fuels media concerns that these increases will lead to unprecedented levels of illness that will place intolerable demands on the NHS and Social Security provision. Hegemonic understandings of 'obesity' can therefore be linked directly to a biomedical definition: Koppelman states in her study of University courses and syllabi that the fat person can be presented as 'medically disordered, pathological, a patient to be treated, counseled, and perhaps 'healed' $(2009,216)$.

There has been a sustained critique of the BMI, the epidemiological evidence of any exponential increase in weight, and even of the link of weight to ill health (Campos et al 2006; Flegal, et al, 2013), but what concerns most critics is the hegemonic status of 'calories in, calories out' energy imbalance models of obesity which lend themselves to individualised 'lifestyle' causes and cures for obesity, namely food intake (excessive/restrict) and exercise (none/more). There is considerable criticism of these models (see Campos et al, 2006): the reduction of health status to weight is worrying because it largely ignores structural determinants of health and there is increasing evidence for us to question whether anti-obesity measures based on these models actually work (Warin, et al, 2015; Monaghan, Bombak, and Rich 2017). Additionally a range of complications and challenges that having a chronic illness or disability might bring are also ignored, including social isolation, reduced mobility, cost of food, difficulty in preparing food, and difficulty in participating in mainstream physical activities and classes. Despite these critical concerns, energy-imbalance 
models have been confidently circulated across the media with the consequence that weight is understood as controllable (Saguy, Frederick, and Gruys 2014).

It has been roundly argued that the suturing of weight to health has meant that health is entering the cultural imaginary as a state that falls within personal control (see Gurrieri, Previte, and Brace-Govan 2013). As such, prevailing understandings of obesity complement neoliberal individualism because the focus remains on individual bodies and the individual blame that can be attributed to them. More specifically, fat starts to emerge in a socio-cultural landscape characterised by 'healthism'. Healthism was coined by Crawford (1980) to refer to the impact of socio-political and economic changes on how health is defined, understood and experienced. He argued that health was shifting from a description of an illness-free state to a site of personal performances and surveillance. Not only has health become something one does, but correct and visible performances become markers of mature, moral personhood and responsible citizenship (Gard and Wright 2005). In this context, the possession of a fat body is a visible mark of a stigmatised identity (Monaghan, Bombak, and Rich 2017; Aphramor 2005): overweight or obese people are always and already regarded as 'health offenders' (Tischner 2013,5) whose health problems are considered selfinflicted (Klos et al, 2015). Additionally, in the context of neoliberal rationalities and particularly austerity, this 'offence' is represented as having an impact on the health care of other citizens because of the 'burden' obesity places on already overstretched (under-funded) welfare services: the fat body then, becomes a concern of us all, encouraging a degree of social acceptability towards the everyday humiliation and prejudice towards larger people to 'encourage' them into good health practices (Major et al, 2014). Lee Monaghan concludes that obesity has become so associated with 
'badness and sickness' that 'fat may as well be a four letter word' (Monaghan, 2007, $605)$.

This goes some way to explain the attraction of fat for poverty porn: the association of fat with 'badness and sickness' sits well with the reality television genre which has been likened to a modern-day 'freak show' (Backstrom 2012), but more significantly, fat bodies offer an acceptable target for ridicule or suspicion in ways other bodies say those with heart disease - do not. Yet, the framing of disability by fat achieves a specific function: our discussion so far suggests that fat has a reductive ability: it reduces a range of complex illnesses, impairments and mobility issues to matters of weight and, via the logics of the obesity epidemic, to matters of personal control and responsibility. This is significant because Morrow $(2015,199)$ argues that in 'fatphobic cultural imaginary, fatness is inseparable from disability' because both are culturally intertwined with illness and sickness. Our concern here is that as illness/ impairment become subsumed by fat/obesity and associated notions of individual control, disability as a 'deserving' ground for state support can be more readily contested on the grounds that (some) disabilities can be reversed through personal will and determination.

In the remaining sections of this paper we discuss how Steve and Michelle, the stars of Bene£its Too Fat, are repeatedly and variously represented as being either reluctant to apply personal control to their lives and their purportedly 'reversible' impairments and illness, or being deceitful (to themselves and others) in their attempts to exercise this responsibility. 


\section{Framing Steve and Michelle}

In this section we consider Butler's (2009) observation that to frame involves 'planting evidence' of 'guilt'. We start with the programme's title, Bene£its Too Fat to Work. State benefits could be understood as a necessary provision for some people in society who need support to live a comfortable and dignified lifestyle. State benefits help a range of different people, young and old, with disabilities or chronic illness and people finding themselves out of work for a range of different reasons. Yet recent media discourse in the UK has focused on the rising cost of benefits which many news outlets deem too extravagant at a time of economic recession (Aleksia 2012). For more than a decade some of the tabloid press have continued to carve out the folk devil of the benefit scrounger who is taking the money off hard-working tax-paying people by fooling the government to believe they are in need of financial help. Benefits: Too Fat to Work consolidates the idea of this immoral figure and reduces the complex social issue of health inequalities across class, disability and other factors to the single issue of money. Pound signs are embedded into the word benefits to underline an 'out of control' benefits bill.

We now focus on how key participants Steve and Michelle, and the social types they are assumed to represent, are 'guilty' of benefit dependency and poor selfmanagement.

Off screen Narrator: 'In Plymouth on the South Coast, $60 \%$ of adults are overweight or obese. Two are Steven Beer and Michelle Combe. Steve weighs 31 Stone and Michelle tips the scales at 23 stone.' 
As we can expect from our discussion so far, the master frame positions Steve and Michelle in terms of their weight but in particular ways: as the narrator offers us facts about the number of overweight people in their area, the film footage focuses on a fast food outlet in their home town to make a clear visual link between obesity and poor lifestyle choices (in a twist of narrative continuity this will be the same outlet that Steve and Michelle will be 'caught at' celebrating their first anniversary by the Daily Mail). The programme then introduces Steve and Michele via their weights (31 and 23 stone respectively). These opening shots neatly position Steve and Michelle within the wider obesity epidemic by producing a 'face' to an otherwise anonymous $60 \%$. The significance of their weight is made clear to the audience by repeated mention that their weight costs the 'tax-payer': we learn, for example, that Steve and Michelle 'live in a one-bedroomed flat paid for [by] housing benefits' that 'in total they get two grand a month in handouts'. Later we learn that Steve receives the assistance of a carer 'who comes twice a day' which costs the tax payer 'about eight thousand pounds per year so he can be looked after'. In a matter of seconds then, obesity - and the disabilities it will purport to represent - is folded into a familiar coding of the unemployed white working class circulating in poverty porn. This reproduces mainstream media representations of obesity as a 'white problem' (Gollust, Eboh, and Barry 2012,1549), while tapping into familiar visual and narrative tropes in wider poverty porn that associate the white working class with abject lives and welfare dependency (Jenson 2013).

Benefits Too Fat diverts more attention to Steve than Michelle because while both are unemployed (Michelle 'hasn't had a job in two decades' reports the narrator), it is 
Steve who is 'signed off on the sick' and is in receipt of disability welfare support. There is early mention that Steve suffered a stroke six years ago. The narrator tells us that 'since then he's developed a growing list of health problems', which meant he could no longer work ('Steve used to run a cleaning business') and which led to his increase in size. Steve's dad reminds his son that five or six years ago, the time of the stroke, 'you was thin'. There is a potentially disruptive narrative here that contests the relationship of large weight to illness because Steve may have been thin at the time of his stroke and his weight gain was a consequence of illness not its cause. Yet, any disruption is limited by framing events onto the present: it is Steve's weight now that is the cause of his unemployment. The shift to the present is achieved by the narrator immediately following from her mention of his past stroke with a damning statistic, 'Steve is around 12,000 people in Britain who get disability benefit because they are too fat to work'. This statement sweeps the stroke aside and replaces it with repeated emphasis that fat/weight are the sole concerns: we see, for example, Steve displaying his stomach and describing himself as fat and the narrator helps us to understand that Steve's breathlessness, discomfort and medical distress are all tied to weight; 'Steve's health problems include diabetes and hypertension caused by his weight'. Diabetes and hypertension are difficult to represent visually, so fat stomachs and fat legs fill the screen.

This shift from stroke to fat allows Bene£its Too Fat to circulate a wider prevailing logic that if Steve, and the thousands like him, could 'do' something about his weight, all his health problems would be resolved as would his work status: Steve's father claims 'If he loses weight I can't see any reason whatsoever within two years that he won't be in a fit state to get to work. There is no reason whatsoever'. We see here a 
reproduction of what Jenson (2013a) identifies as a foundational myth of poverty porn: that there is full quality work 'out there' if only individuals made themselves fit for it. Steve tries to call this into doubt by asking 'where's the people out there who will give me a job?' and later when he describes how the Job Centre turned him away because of his weight, Steve asks the camera 'What can you do? Yet, any potential for a critique of employment or the impact of weight discrimination on recruitment is immediately brushed aside by a reproduction of obesity logics that see weight (and therefore health) as controllable - it seems that Steve should be doing something. What emerges is not a question of what work is available in neoliberal conditions (Jenson, 2013a) but the start of an investigation into Steve's character and integrity just what kind of person is he?

\title{
Talking the Talk
}

\author{
Narrator: 'Although Steve struggles to work, he's keen to talk \\ the talk' \\ Steve: 'I was brought up that if you had a family, you look after \\ them and that doesn't mean that you sit on your ass and watch \\ the world go by, you have got to go out there and earn your keep \\ instead of sponging off the system.'
}

In a genre implicated with the demonization of scroungerphobia (Heeney 2015), it is interesting that Steve espouses prevailing distinctions of strivers/shirkers (Valentine and Harris 2014) that suggest that work status is a matter of personal attitude and agency: those who get off their ass and those who don't. We might expect this quote to 
redeem Steve's current worklessness, or at least place him within the category of claimants who are considered deserving because they demonstrate the 'right' attitude towards work. Yet, Bene£its Too Fat, by this incorporation, suggests that even those who advocate anti-welfare sentiments cannot be trusted. This is achieved by introducing Steve's words with 'talk the talk' which is a phrase that describes a mismatch between actions and stated intentions.

This mismatch between his words and deeds is repeatedly demonstrated throughout the documentary, particularly with regard to his eating, a focus, we suggest is enabled and dramatized by the calories in/out logics of the obesity epidemic. For example, the audience learns that Steve attends a weekly management class ('paid for out of his benefits') and a 'compulsory weight-loss programme funded by the tax-payer'. Steve is confident of losing weight, as he heads for his weigh-in he tells us that 'what I am trying to do now is lose $31 \mathrm{~b}$ to get down to 31 stone'. He manages to lose $11 \mathrm{~b}$ and when congratulated, he explains that he has been 'keeping off the fat stuff' and is pleased with his success 'well, that's a pound off, I expected more really... that was really good'. While the audience may be led to question why Steve is so easily pleased at what is a failure to reach his goal, they, the audience is treated to Steve celebrating his weight loss by placing a food order to his local fast food outlet. It is clear he is a regular caller as he says down the phone 'yeah, you've got it [the order] by now, haven't you?' In addition to his large kebab, the audience is also treated to Steve eating the very 'fat stuff' he said he was restricting. That Steve does this knowingly is suggested by his comment 'if anyone comes in, especially Linda [weight management advisor] and sees me eating this, she'll say "why have you got a kebab?".' There is an interesting point that can be made here about visual 
representation: Obesity helps undermine the trustworthiness of the fat disability claimant because there is a doubling of visibility. Not only is body fat highly visible (Tischner 2013) but the types and quantities of food and their consumption are also readily filmatic in way that other 'bad' behaviours are not (film footage of someone sitting on a couch or not exercising would struggle to make the sensationalized impact of someone eating their way through what seem to be large volumes of food). Similarly the cost of take-away food helps to present it as excessive (' $11 \mathrm{~b}$ lost, $£ 11.50$ spent, but best to keep it quiet' reports the narrator). It seems then, that Steve is adept at playing the system: saying what he needs to say, displaying a willingness to change, while engaging in the very behaviours that keep him in what is represented as a lifestyle of idleness and welfare dependency.

\section{Not Walking the Walk}

At seventeen minutes into the programme there is one fleeting, yet interesting remark made on Steve's use of a mobility scooter to aid him on a trip into town. Footage shows both Steve and Michelle on their journey into town alongside the voiceover that stated 'Steve is getting around on a specially strengthened mobility scooter. Paid for out of his benefits'. Although no other reference to the scooter was made throughout the show, that this scene made it to the final edit holds some significance. The use of mobility-scooters has risen in recent years although there has been little attention paid to this in academic literature (May, Garrett, and Ballantyne 2010). There is some ambivalence over mobility scooters in the public domain because they are simultaneously associated with support for people with mobility difficulties and a sort of luxury vehicle for the elderly to add comfort to their lives: scooters are not 
then, straightforwardly associated with disability and impairment in the way a wheelchair is: Jang et al (2017) found that scooter users faced barriers and stigma partly because of the uncertain status of scooters as both disability signifiers and mobility devices. Bene£its Too Fat, true to its title and theme appears to be concerned wholly in demonstrating the cost of 'being too fat to work' and hence the cost of the mobility scooter was the only context in which the aid was discussed. It is unlikely that even a programme like Benefits Too Fat would have commented on the cost of a wheelchair had Steve been using one of these instead. The wheelchair does not evoke the same degree of suspicion around the user's 'authentic' disability status as the mobility scooter due to the users of the latter usually having the ability to walk short distances (and hence calling into question the need for the scooter). For example, later in the programme Steve is seen walking into town (without his scooter) and the narrator remarks that he is 'in a spot of bother ... Steve's health problems including diabetes and hypertension ... caused by his weight means just being on his feet makes him breathless'. So although Benefits finally mentions the impairment issues that Steve has, this information is given around eight minutes after we have seen Steve with his scooter. The mobility scooter and its (unnecessary) purchase/rental from the benefits system has already been established and the list of health problems are only framed as issues caused by his own journey to obesity. In conclusion, the image of Steve using a mobility scooter stresses the liminal nature of Steve's body as being neither disabled or able; as being both dependent (on benefits) and independent (if only Steve could make the right eating and life choices); as owning both a worthless body but one with the potential to work and contribute fully to society. We are left with deepening suspicion of Steve's claims to ill health and we are possibly left to question whether his dependency both on the state and his scooter 
is preventing him from getting the much needed exercise that is suggested as the solution to obesity in medical discourses.

\section{The Big Benefits Wedding}

Questions about the way poor people spend their money have long formed part of the moralised classifications of deserving and undeserving poor: Rowntree's (1901:5) report made mention of concerns about 'drink, betting and gambling, ignorant or careless housekeeping and over improvident expenditure' (cited in Cameron, Smith, and Tepe-Belfrage 2016,407). It may be expected then, that Bene£its Too Fat would provide a regular tally of the Beer's inappropriate spending habits. There has already been mention of the cost of a take away, but Benefits Too Fat reserve its commentary for what the narrator describes as the Beer's 'big benefits wedding'. We suggest that the wedding, an event readily understood as costly, encourages audiences to draw unfavourable conclusions about the ways benefits are spent by extrapolating from individual, seemingly 'authentic' stories of individuals and specific events (McEnhill and Bryne, 2016).

From the start of the programme, Steve defends his right to hold a wedding: 'there's loads of people out there who's on benefits who get married, of course they do, and they find a venue and have their friends as well, so why can't I'. Steve's assertion of entitlement is potentially powerful here: Kolarova (2012) has argued that disabled people have often been forced to redeem self-pride and accept an imposed stigma and isolation in exchange for their 'rightful' access to welfare. Yet, Steve's claim for entitlement is immediately undermined by the following exchange: 
Steve: This is wedding number four.

Michelle: Six.

Steve: Six then, wedding number six.

As Steve is seen to be careless even in his memory of what are culturally held to be significant events, the wedding becomes a site where specific framings can be reiterated: Steve is aware that he cannot afford a big wedding 'at the end of the day, if you want to get married and you are on benefits and stuff then I'm afraid you got to miss out on things' yet he later lists his desire for the 'release of doves', 'canopies', official photographers, a $£ 200$ car, 'an all day buffet' and new suit. The wedding then, allows Benefits to reiterate that Steve might be displaying the correct attitude but that this is further example of his 'talking the talk'. The consequence is that the tax-payer picks up the 'lion's share of the cost' and the narrator gestures towards the waste by pointing out that the pizza buffet (the Beer's 'favourite' fast food) cost a thousand pounds.

The wedding and pizza is significant because it goes against the wider austerity message of careful household economics. Cultural ideals about constrained household spending circulate through a political rhetoric that forges strong parallels between the 'greed, consumption and profligacy of both the State and the household' (Cameron, Smith, and Tepe-Belfrage 2016). These links help circulate understandings of austerity as a commonsense and logical strategy of cutting spending to reduce debts while embedding the notion that indebtedness is a problem shared by all citizens. The complexity of State economics is reduced to models similar to those we have already observed in the obesity epidemic to explain health - money/ calories in and money/ calories out. Restriction on spending, in common with a disciplined restriction of 
food, has a performative and aesthetic dimension. Jensen (2013b) observes how recent thrift programming repositions hardship has a site of fun, creative challenges of up-cycling, foraging and mending. This 'new thrift' draws more surveillance onto household spending habits (not, notably, upon those of the rich elites) and it deftly abstracts the brutal struggle of those surviving in economic restraints with little to no relief. In contrast then to the Superscrimpers, and the fashionably frugal, sits Steve's sixth wedding - a wedding characterized not by the new 'aesthetics of austerity' (Jensen, 2013b, 64) but by an abundant consumption coded as unhealthy by obesity discourses and as tasteless by the sensibilities of the 'new thrift'. As audiences are encouraged to regard Steve as a representative of a wider social type (one of the $60 \%$ of overweight people in Plymouth, one of 12,000 who are on benefit because they are 'too fat to work'), Steve's spending gestures towards the profligacy of others who are also regarded as having a doubtful claim on the State.

\section{Discussion}

This paper is not suggesting that the construction of deserving and undeserving poor is new (see Stone 1984), nor does it argue that the association of poverty with character or milieu is unique to poverty porn (see Korte and Zipp 2014). Our intention is to demonstrate that these constructions and associations are aggressively reproduced within the context of neoliberal austerity with specific consequences for disability claimants. To reiterate, we are not simply witnessing a 're-run' of a moral panic over welfare claimants, rather austerity is a strategic restructure of 'welfare to refashion economic and social relations on a grander scale' (Morris 2016,101). The key mechanisms for this refashioning are argued to be social division, stigmatization 
(Hayes 2017, 23) and scapegoating (O’Flynn, Monaghan, and Power 2014) which we argue can be observed in poverty porn.

Our analysis suggests that it is possible and critically desirable to regard the framing ('setting up') of disability claimants as central to what Wacquant (2008) terms as advanced marginality, which, amongst other processes, proceeds to penalize urban poverty through a series of ever more targeted social exclusions. In particular, Wacquant makes two arguments: the first is that poverty is the consequence of structural violence from above and not something that can be explained away by personalised accounts of lifestyle (despite what Bene£its Too Fat may suggest). Secondly, that the chances of class solidarity, collective action and resistance are drastically reduced when marginalised populations are encouraged to distance themselves from those rendered more abject: in simple terms, he argues that the conditions of advanced marginality encourage the urban poor to turn against each other in order to lay claim to their own worth. Returning to our earlier discussion of Briant, Watson, and Philo (2013) analysis of news media, we observed how a narrowing of focus firstly brings the disabled claimant population into specific view, by distinguishing them from a wider claimant population, and then fragmenting this group into smaller demographics of authentic and fraudulent claimants. Additionally, in Runswick-Cole and Goodley's (2015) analysis of Benefit Street, there is evidence of a more targeted attempt to drill down into disability categories themselves in order to foreclose the very means by which people can claim on social security (learning disabilities seem to offer stronger 'authenticity'). Our reading of Wacquant (2008) suggests that disability claimants are caught up in the repeated construction of 'authentic-not-fraudulent' as part of their performance of legitimacy. If this is the 
case then the circulation of obesity logics in poverty porn (which render fat/ health as controllable) help to frame those who attempt to claim authenticity as being potentially duplicitous (discussed above as 'talking the talk'). Additionally, as obesity folds into the class dynamics of poverty porn, disability becomes associated with the 'unhealthy lifestyles and excessive consumption' stereotypes which have been attached to the white working class (Heeney, 2015, Gollust, Eboh, and Barry 2014) to reemphasize the notion that worklessness is a voluntary choice reflecting a personal 'preference for idleness and a life of welfare benefits' (MacDonald, Shildrick, and Furlong 2014, 31).

The consequence is an overdetermination of suspicion that is fuelled by commonsense and tacit knowledge of weight, the personal character deficits exhibited by fat bodies, and of classed Others (Heeney 2015). We regard this as a necessary strategy to silence any structural explanations for poverty and replace them with accounts of personal idleness and wastefulness (Cameron, Smith, and Tepe-Belfrage 2016; Runswick Cole and Goodley 2015), while encouraging a hardening of public opinion towards Others and a suspicion over their right to claim welfare (Valentine and Harris 2014). As suspicion is widely and repeatedly cast, public opinion can be orientated to support 'solutions' to the threats posed by Others: work-fare, benefit reductions, increased state-surveillance, harsher eligibility tests, and privatization of the welfare system (Morris 2016; Piven 2015).

\section{Conclusion}

In this paper we have asked what cultural work fat achieves within the context of poverty porn. Our focus on the abjection of larger disabled people has allowed a sharper sociological critique into the specificity of the scapegoats paraded in poverty 
porn: we have demonstrated how the utilization of existing 'commonsense' knowledge relating to obesity can overdetermine the disabled welfare claimant as suspicious in this reality television genre. In particular, we have argued that while anti-welfare commonsense may be disrupted by exceptional cases and notions of the 'deserving poor' (Watkins-Hayes and Kovalsky 2017), obesity may be used to undermine the creditability of those exceptional cases by casting doubt on authentic hardship. Disability provides a particularly useful site for this application of obesity because to be regarded as 'legitimate' the disabled person it seems, needs to be recognized as 'authentically' disabled by the public to avoid stigmatisation. Freidson's (1988) seminal work demonstrated the importance of lay legitimation of the sick role that, if granted, permitted the ill person access to the rights and obligations that the role granted. Applied to more current day 'scrounger' discourse, it appears that the process of disability legitimation is similarly subjectively applied and those with disabilities that might not be visible, or are regarded in some way as 'caused' by 'immoral' practice (e.g.by having obese bodies that may cause impairment) are primed for stigmatization and distrust. Furthermore, obesity as a lifestyle casts further doubt on the systems that classify need and deservedness in the first place: the framing in Bene£its Too Fat suggests that the welfare system is itself easily duped through its own lax gatekeeping. The overall thrust of such messaging is that poverty is displaced from critical and political attention by figures of suspicion and threat. We suggest that representations of fat allows the further contestation of a number of impairments while avoiding the politically-risky work involved in directly challenging the status and entitlement of disabled welfare claimants.

\section{References}


Aleksia, A. 2012. Why We're Not Benefit Scroungers: Life with Chronic Illness or Disability in Modern Britain. Oxford: Aleksia Publishing Writers World.

Allen, K ., I.Tyler, and S, De Benedictis. 2014. “Thinking with 'White Dee: The Gender Politics of 'Austerity Porn”. Sociological Research Online 19 (3) 2 $<$ http://www.socresonline.org.uk/19/3/2.html $>$

Aphramor, L 2009. "Disability and the anti-obesity offensive". Disability and Society 24 (7): 897-909

Aphramor, L. 2005. "Is a Weight-centred Health Framework Salutogenic? Some Thoughts on Unhinging Certain Dietary Ideologies”. Social Theory \& Health 3 :315340

Backstrom, L. 2012. "From the Freak Show to the Living Room: Cultural Representations of Dwarfism and Obesity”. Sociological Forum 27 (3): 682-707

Bates, K.,D. Goodley, and K. Runswick-Cole. 2017. “ Precarious Lives and Resistant Possibilities: The Labour of People with Learning Disabilities in Times of Austerity Disability and Society 32 (2): 160-175.

Biressi, A., and H.Nunn. 2013 Class and Contemporary British Culture. London:Palgrave

Briant, E., N. Watson, and G. Philo. 2013 "Reporting Disability in the Age of Austerity: The Changing Face of Media Representation Of Disability And Disabled 
People In The United Kingdom And The Creation Of New 'Folk Devils'”. Disability and Society 28 (6): 874-889

Brooker, P., J. Vines, S. Sutton, J. Barnett, T. Feltwell, and S. Lawson. 2015

"Debating Poverty Porn on Twitter: Social Media as a Place for Everyday SocioPolitical Talk" Paper presented at the $33^{\text {rd }}$ Annual ACM Conference on Human Factors in Computing Systems. Seoul, Republic of Korea, April 18 - 23, 2015

Butler, J. 2009 Frames of War: When Life is Grievable? London, New York: Verso

Campos, P., A.Saguy,P. Ernsberger, E. Oliver, E, and G. Gaesser. 2006. “The Epidemiology of Overweight and Obesity: Public Health Crisis Or Moral Panic?”. International Journal of Epidemiology 35(1): 55-60.

Cameron, A., N. Smith, and D. Tepe-Belfrage. 2016 "Household Wastes:

Disciplining The Family In The Name Of Austerity” British Politics 11 (4): 396-417

Cleary, K. 2016. “Misfitting and Hater Blocking: A Feminist Disability Analysis of the Extraordinary Body on Reality Television “ Disability Studies Quarterly 36 (4): http://dsq-sds.org/issue/view/153 
Crawford, R. 1980. "Healthism and the Medicalization of Everyday Life", International Journal of Health Sciences 10: (3): 365-388

\author{
Deeming, C. 2015 "Foundations of the Workfare State - Reflections on the \\ Political Transformation of the Welfare State in Britain" Social Policy \\ \&Administration. 49(7): 862-886.
}

De Benedictis, S., K.Allen, K. and T. Jensen. 2017. "Portraying Poverty: The Economics And Ethics Of Factual Welfare Television”. Cultural Sociology 11 (3): $337-358 /$

Farrell, A.E 2011 Fat Shame: Stigma and the Fat Body in American Culture New York: New York University Press.

Flegal, K.M., B.K,Kit, H. Orpana, and B.I. Graubard. 2013 “Association of All-Cause Mortality With Overweight and Obesity Using Standard Body Mass Index Categories: A Systematic Review and Meta-analysis” Journal of the American Medical Associatio, 309 (1):71-82.

Flint, S.W., and J, Snook. 2014 “Obesity And Discrimination: The Next 'Big Issue?" International Journal of Discrimination and The Law 14 (3): 183-193.

Freidson, E. 1988. Profession on Medicine: a study of the Sociology of Applied Knowledge. Chicago: Chicago University Press. 
Gard, M., and J. Wright. 2005 The Obesity Epidemic: Science, Morality And Ideology London: Routledge.

Ghoshal, R. 2009 “Argument Forms, Frames, and Value Conflict: Persuasion in the Case of Same-Sex Marriage” Cultural Sociology 3 (1): 76-101.

Gollust, S.E., I. Eboh, and C.L. Barry. 2012 "Picturing Obesity: Analysing The Social Epidemiology Of Obesity Conveyed Through US News Media Images" Social Science and Medicine 74:1544-1551

Grant, S.L., T Mizzi, and J.Anglim. 2016. “Fat, Four-Eyed And Female’ 30 Years Later: A Replication Of Harris, Harris, And Bochner's (1982) Early Study Of Obesity Stereotype" Australian Journal of Psychology 68 (4): 290-300

Gurrieri, L., J. Previte, and J. Brace-Govan. 2013. “Women's Bodies As Sites Of Control: Inadvertent Stigma And Exclusion In Social Marketing” Journal of Macromarketing, 33 (2): 128-143.

Heeney, J. 2015 “Disability Welfare Reform And The Chav Threat : A Reflection On Social Class And 'Contested Disabilities” Disability and Society 30 (4): 650-653

Jang, S., B. Mortenson, L. Hurd, and R.L.Kirby. 2017. "Blurred Lines: The Liminality Of Mobility Scooters" Abstracts, Poster Presentations for Qualitative 
Health Research Conference. International Journal of Qualitative Methods. Vol 16 pp.1-21.

G. L. Jenkin, L. Signal and G. Thomson 2011 Framing Obesity: The Framing Contest Between Industry And Public Health At The New Zealand Inquiry Into Obesity obesity Reviews (2011) 12, 1022-1030

Jensen, T 2013a “A Summer of Television Poverty Porn” Sociological Imagination, http://sociologicalimagination.org/archives/14013.

Jensen. T 2013b “Austerity Parenting” Soundings 55: 60-70

Jensen, T. and I. Tyler. 2015 “'Benefits Broods': The Cultural And Political Crafting Of Anti-Welfare Commonsense' Critical Social Policy, 35(4):1-22.

Jutel.A. 2009.” Doctor's Orders: Diagnosis, Medical Authority And The Exploitation Of The Fat Body." In Biopolitics and the 'Obesity Epidemic edited by Wright.J., and V.Harwood, 60-77. London: Routledge.

Klos, L.A., C. Greenleaf, N. Paly., M.M Kellser, C.G .Shoemaker, and E.A. Suchla, 2015 "Losing Weight On Reality TV: A Content Analysis Of The Weight Loss Behaviours And Practices Portrayed On The Biggest Loser". Journal of Health Communication 20:639-646

Koppelman, S. 2009 "Fat Stories in the Classroom What and How are the They Teaching About us?” In The Fat Studies Reader, edited by Rothblum, E. and S. 
Solovay, 213-220. New York: New York University Press.

Major, B., J.M. Hunger, D.P. Bunyan, and C.T. Miller. 2014 "The Ironic Effects Of Weight Stigma”. Journal of Experimental Social Psychology 51: 74-80.

May, E., R. Garrett, and A.Ballantyne. 2010. Being Mobile: Electric MobilityScooters And Their Use By Older People. Ageing and Society 30: 1219-1237.

McDonald, R., T. Shildrick and A. Furlong. 2014. "Benefits Street And The Myth Of Workless Communities” Sociological Research Online 19 (3):

<http://www.socresonline.org.uk/19/3/1.html>

McPhail, D. 2009 “'What Do To With The ‘Tubby Hubby’? :The Crisis Of Masculinity And The Nuclear Family In Early Cold War Canada". Antipode 41 (5): 1021-1050.

Mirsky, N 2014. "Benefits Street struck a nerve - exposing how vital a documentary it is". The Guardian Friday 10 January 2014 10.30 GMT https://www.theguardian.com/commentisfree/2014/jan/10/benefits-streetdocumentary-reality

Monaghan, L.F., A. E.Bombak, and E. Rich. 2017.” Obesity, Neoliberalism And Epidemic Psychology: Critical Commentary And Alternative Approaches To Public Health" Critical Public Health Pages 1-11 |Aug 2017, Published online: 05 Sep 2017 
Monaghan, L .F. 2007. “Body Mass Index, Masculinities And Moral Worth: Men’s Critical Understandings Of 'Appropriate' Weight-For-Height” Sociology of Health and Illness 29 (4): 584-609.

Monaghan. L.F., R. Colls, and B. Evans. 2013. "Obesity Discourse And Fat Politics: Research, Critique And Interventions" Critical Public Health 23 (3): 249-262

Morris, L. 2016 “The Moral Economy Of Austerity: Analysing UK Welfare Reform”. The British Journal of Sociology 67 (1): 97-117/

Mollow, A. 2015. “Disability Studies Gets Fat “ Hypatia 30 (1): 199- 216

O’Flynn, M., L.F. Monaghan., and M.J. Power. 2014. “Scapegoating During a Time of Crisis: A Critique of Post- Celtic Tiger Ireland”Sociology 48(5):921-937

Puhl, R.M and C. A. Heuer .2009. "The Stigma of Obesity: A Review and Update" Obesity 17 (5) : 941-964

Raisborough, J .2014. "Why we should be watching more Trash TV: Exploring the value of an analysis of the makeover show to Fat Studies Scholars" Fat Studies: An Interdisciplinary Journal of Body Weight and Society 3(2)155-165

Runswick-Cole, K and D. Goodley. 2015 "Dispovertyporn: Benefits Street And The Dis/Ability Paradox” Disability and Society 30 (4) 645-649 
Saguy, A., Frederick, D and Gruys, K. 2014 "Reporting Risk, Producing Prejudice: How News Reporting On Obesity Shapes Attitudes About Health Risk, Policy And Prejudice", Social Science and Medicine.111: 125-133.

Soldatic, K ., and H. Morgan. 2017 “The Way You Make Me Feel’ Shame And The Neoliberal Governance Of Disability Welfare Subjectivities In Australia And The UK" in Edges of Identity: The Production Of Neoliberal Subjectivities, edited by Louth, J and M. Potter, M, 106-133. Chester: University of Chester Press.

Stone, D.A. 1984 The Disabled State Philadelphia: Temple University Press.

Shugart, H.A. 2010 "Consuming Citizen: Neoliberating the Obese Body". Communication, Culture, and Critique 3(1): 105-126.

Tischner, I. 2013 Fat Lives: A Feminist Psychological Exploration .London: Routledge.

Tyler, I. 2013 Revolting Bodies: Social Abjection and Resistance in Neoliberal Britain. London: Zed Books.

Tyler, I 2008 “Chav Mum Chav Scum” Feminist Media Studies 8(1): 17-34

Wacquant, L . 2008 Urban Outcasts: A Comparative Sociology Of Advanced Marginality Oxford: Polity 
Warin, M., T. Zivkovic, V. Moore, P.R.Ward, and M. Jones. 2015. "Short Horizons And Obesity Futures: Disjuctures Between Public Health Interventions And Everyday Temporalities”. Social Science and Medicine 128:309-315.

Watkins-Hayes, C., and E. Kovalsky, E. 2017 “The Discourse of Deservingness:

Morality and the Dilemmas of Poverty Relief in Debate and Practice" in The Oxford Handbook of the Social Science of Poverty Edited by David Brady and Linda M.

Burton, 194-220. 